\title{
PRMT1 wt Allele
}

National Cancer Institute

\section{Source}

National Cancer Institute. PRMT1 wt Allele. NCI Thesaurus. Code C134686.

Human PRMT 1 wild-type allele is located in the vicinity of 19q13.33 and is approximately $13 \mathrm{~kb}$ in length. This allele, which encodes protein arginine N-methyltransferase 1 protein, is involved in the methylation of histone $\mathrm{H} 4$ and chromatin. 